\title{
Brazilian Tropical Grassland Ecosystems: Distribution and Research Advances
}

\author{
Vitor Del' Alamo Guarda1, Renato Del' Alamo Guarda² \\ ${ }^{1}$ Brazilian Agricultural Research Corporation, Embrapa Fisheries and Aquaculture, Palmas, Tocantins, Brazil \\ ${ }^{2}$ Nuscience.Itupeva, São Paulo, Brazil \\ Email: vitor.guarda@embrapa.br
}

Received 23 January 2014; revised 24 February 2014; accepted 5 March 2014

Copyright @ 2014 by authors and Scientific Research Publishing Inc.

This work is licensed under the Creative Commons Attribution International License (CC BY).

http://creativecommons.org/licenses/by/4.0/

(c) (;) Open Access

\begin{abstract}
A few decades ago we sought the understanding of the functioning of Brazilian ecosystems. During these years, changes in the way land use were influenced primarily by economic issues involving the process of valuation of land in different regions. Furthermore, developments in research have provided productive increments that were well characterized in some phases. This paper aims to trace a brief history of the distribution of grassland ecosystems in Brazil and show how it has been the advances in research on forages and pastures in the country, pointing its evolution, transition times and trends. Moreover, it purports to show a perspective of the dynamics of occupation of Brazilian territory by these ecosystems. The information is presented on three occasions, seeking to encourage understanding of where livestock grazing occurs and how the dynamics of occupation of the area was favored by the search. Also, it shows how the research was fundamental for Brazil occupy little arable areas considered, making the country one of the largest producers of cattle in the world.
\end{abstract}

\section{Keywords}

Grassland Ecophysiology; Cerrado; Grazing Management; Plant-Animal Relationship

\section{Introduction}

Agricultural production plays a large role in Brazil's Gross Domestic Product, GDP, and, in this scene, the livestock does not appear as a simple adjunct. Brazil is the largest beef exporter in the world and in 2006, exported more than 1.2 million tons of beef carcass. Of all cattle produced in Brazil, the pastures are used as the exclusive source of food for approximately $90 \%$ of the herd.

Pastures represent the dominant landscape in Brazil and are responsible for $50.6 \%$ of the national land area; 
that is, according to [1], about 159 million hectares of native and cultivated pastures with widespread presence throughout the country, highlighting the movement of historical incorporation of effective occupation of the interior of Brazil since colonial times.

A growing demand for natural resources and animal products to deal with rising human population has put enormous pressure on the pasture ecosystem. The high amounts of degraded pastures have concerns about various organizations and institutions, as well as the scientific community. It's originated and substantially increased funding and research initiatives in recent years, in an effort to restore degraded areas, increase pasture productivity, besides seeking effective management practices to sustain the productivity and operation of grassland ecosystems in Brazil.

Due to its socio-economic and also environmental importance, pasture ecosystems have become a priority issue in research and have attracted much national and international researchers attention. The aim of this review is to provide a little overview of the distribution, especially the Cerrado region, the current knowledge, besides the increase and perspectives on the understanding of grassland ecosystems of Brazil.

\section{Brazilian Pastures Ecosystems: Types and Distribution}

The establishment of pasture in forest areas began almost at the beginning of lastcentury and intensified the $30 \mathrm{~s}$ and 40. The deforestation aimed the land preparation, at medium and long term, to be used with annual crops corn, cotton, beans - and especially for coffee plantations in the best plots. Within this projection of agriculture, the ox would be the pathfinder element in the initial stages of replacing the dense forests for export and consumption crops [2]. According to the author, the grass that dominated with almost absolute exclusivity until the 30's and 40's belonged Melinisminutiflora (molasses grass), Panicum maximum (guinea grass), Hyparrheniarufa (thatch grass) and Brachiariamutica (angola grass and para grass). The four species studied responded to the growth of tropical/subtropical Brazil'slivestock since its inception, occupying a very large variety of natural and induced ecosystems, several million hectares, from north to south (Figure 1). In the case of the southern region, because of its climate, the first introductions of new plant species were Loliummultiflorum (ryegrass) and Trifoliumspp (clover), mainly followed by others originating in temperate/subtropical climate.

Currently, the vast majority of pasture is perennial, native or cultivated. The native pastures are present mainly in the regions of the Pantanal (Axonopuspurpusii, Panicumlaxum, Hemarthriaaltíssima, Paspalumplicatulum, Paspalumoteroi, Leersiahexandra and Hymenachneamplexicaulis), wetland regions of North (Trachypogon sp, Axonopuspulcher, Axonopuspurpusii, Axonopusamapaensis, Elyonurus sp., Mesosetumaltum, Mesosetumloliiforme, Paspalumcarinatum, Paspalumgardnerianum and Panicumnervosum) Caatinga (Chlorisorthonoton, Brachiariaplantaginea and Macroptiliummartii) and Pampas (Aspiliamontevidensis, Eupatorium buniifolium, Nothoscordum sp., Sisyrinchiummicranthum, Scutellariaracemosa, Solanum sp., Verbena montevidensis, Apiumleptophyllum, Juncus sp. And Carex sp.) region. These regions have specific environmental characteristics which makes the process of succession by another forage crop harder. Over time, there has been an increase in cultivated pasture areas in Brazil and a reduction in natural rangeland areas. According to [1], there was a small increase in planted pastures-when analyzing the total Brazil-1.7 million hectares. However, the data of the Major Regions and Federation Units (Figure 2), show an increase of 5.8 million hectares in the northern region, corresponding to $39.7 \%$ more than in the previous census, concentrated in the states of Rondônia (increase of 1.9 million hectares or 75.8\%) and Pará (increase of 3.2 million hectares or 55.3\%). In the Northeast, there was an increase of 2.4 million hectares, accounting for $20.1 \%$, concentrated in the states of Maranhão, with 1.1 million hectares (38.2\%) and Bahia, with 1.0 million hectares (15.9\%). On the other hand, in other regions, we found a reduction in the areas of planted pasture, under 3.7 million hectares (or 18.3\%) in the Southeast, almost concentrated in São Paulo, with 3.0 million hectares (42.9\%). In the South, there was a reduction of 2.2 million hectares, representing 31.7\% less in the region, concentrated in the state of Paraná (least 1.9 million hectares or $35.9 \%$ in the state). The Midwest region showed a reduction of 533 thousand hectares or less $1.2 \%$, concentrated in the states of MatoGrosso do Sul (981,000 hectares or 6.2\%) and Goiás, down 1.6 million hectares (11.9\%). The final amount of the region was balanced, because there was an increase of 2.1 million hectares in MatoGrosso (14.1\%).

The numbers indicate that there has been great change among states, with a displacement of pastures to the north of the country. The observation of this occupation process suggests strengthening the position of mobility, 


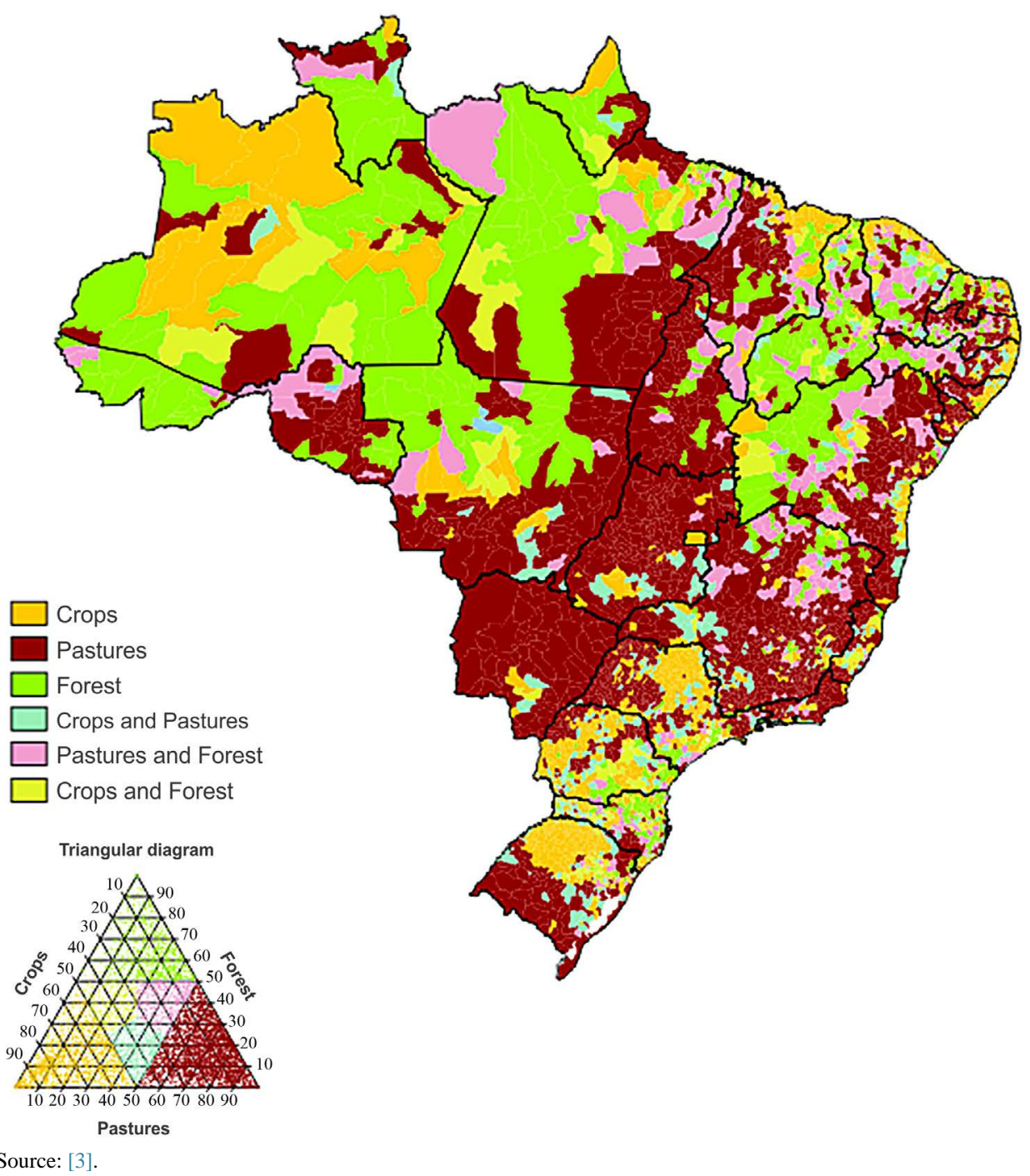

Figure 1. Brazilian land use in 2006.

in large territorial extensions, livestock frontier country, mainly in the states of MatoGrosso do Sul, northern MatoGrosso and Maranhão.

This increase in pasture areas occurs mainly in the Cerrado region (Figure 3). The high land cost and competitiveness with crops in regions with best quality soils provided this change on cattle industry for marginal regions of Brazil. Even little used by producers and consultants, agricultural research data has been generated and, combining technical liming and fertilization of the soil, besides grazing management, these areas develop their productive potential, making the activity competitive and generating profits.

The Brazilian grassland ecosystems, in general, are formed with one single grass. In Brazil, the animal production system in pasture is based on the use of Panicum and Brachiaria grass. These grass are distributed among various soil conditions, topography and environmental conditions, different ways of management and use, besides the use or not proper cultural practices.

According to Rally Farming, project which traveled 52,000 kilometers at Brazil in 2012, approximately 68.2\% of the pastures are covered by brizantha cultivars. Other types of cover crops (decumbens, ruziziensis, humidicola, etc.) represent another $9.1 \%$ of grass present on farms and Panicumgrass totaled $10.2 \%$ of all samples, as can be seen in Figure 4.

Even with increased grazing areas, especially in the northern region of Brazil, the last agricultural census shows for the first time, a reduction in the area of grassland in the country (Table 1). This fact, combined with 


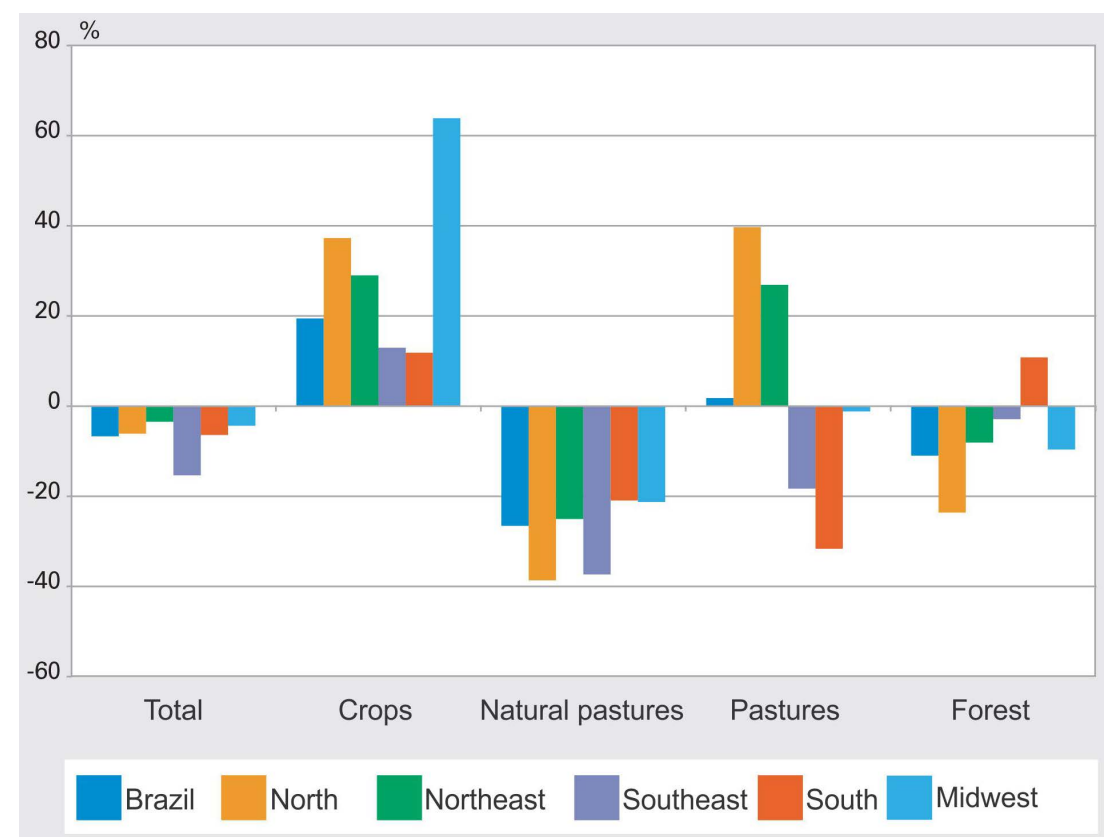

Source: [1].

Figure 2. Percentage change in land use, by Major Regions, the main types of use2006.

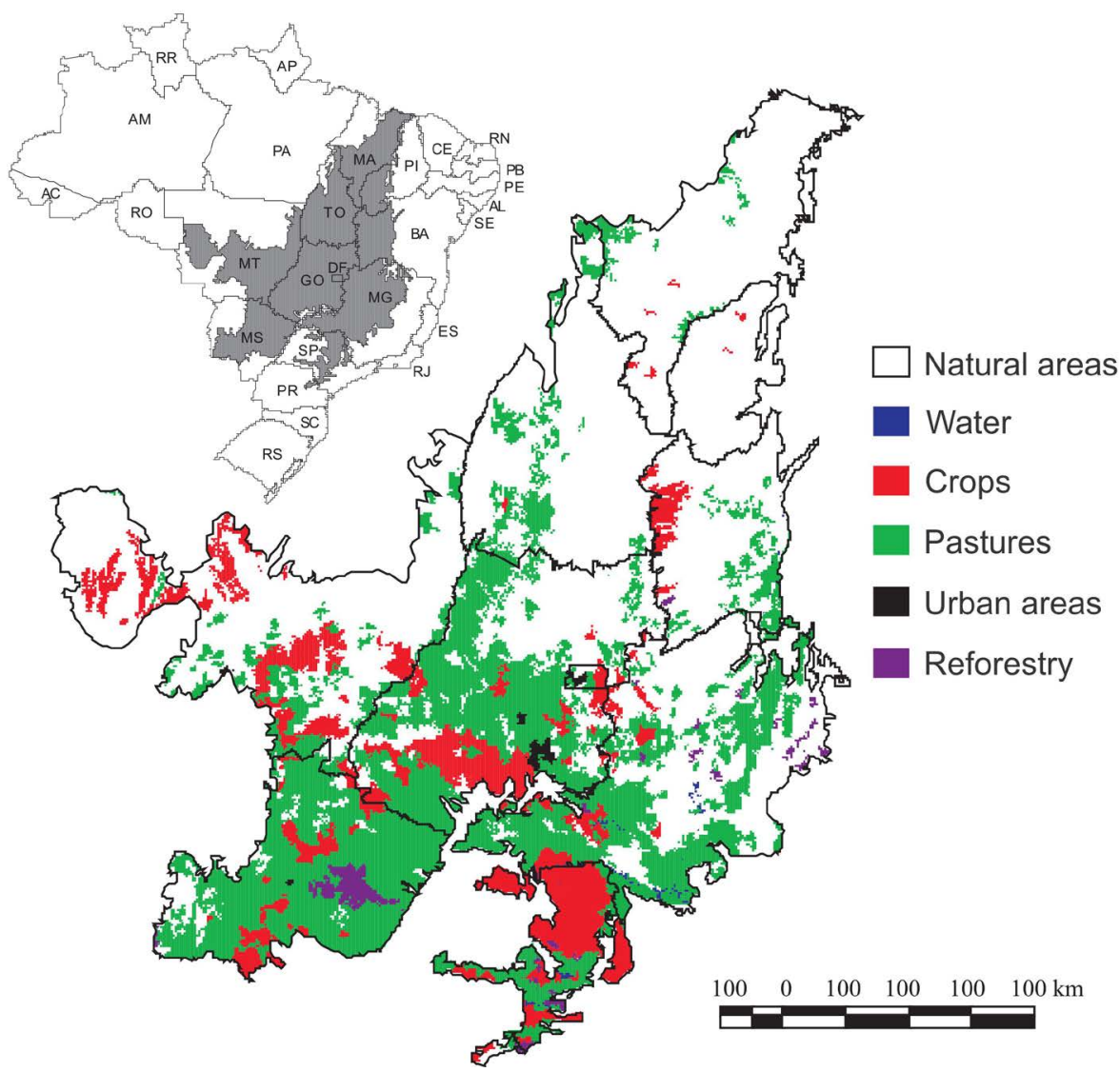

Source: [4].

Figure 3. Spatial distribution of land use classes in the Cerrado biome of the year 2002. 


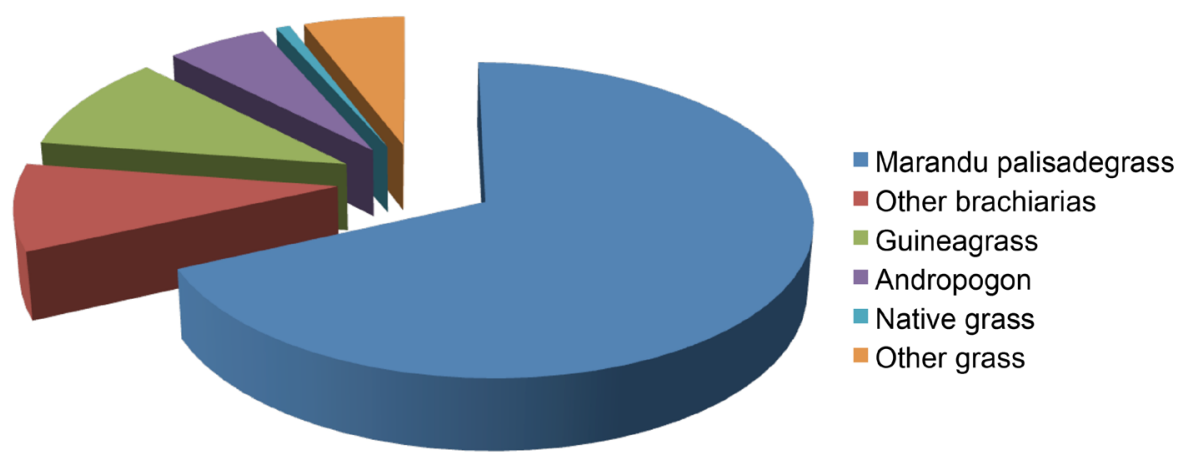

Source: [5].

Figure4. Forage present on farms.

Table 1. Evolution of land use in Brazil.

\begin{tabular}{ccccccc}
\hline \multirow{2}{*}{ Structural Data } & \multicolumn{7}{c}{ Census } \\
\cline { 2 - 7 } & $\mathbf{1 9 7 0}$ & $\mathbf{1 9 7 5}$ & $\mathbf{1 9 8 0}$ & $\mathbf{1 9 8 5}$ & $\mathbf{1 9 9 5 - 1 9 9 6}$ & $\mathbf{2 0 0 6}$ \\
\hline Establishments & $4,924,019.00$ & $4,993,252.00$ & $5,159,851.00$ & $5,801,809.00$ & $4.859,865.00$ & $5,175,489.00$ \\
Total area (ha) & $294,145,466.00$ & $323,896,082.00$ & $36,485,442.00$ & $374,924,929.00$ & $353,611,246.00$ & $329,941,393.00$ \\
Land use (ha) & & & & & & \\
Permante crops & $7,984.068 .00$ & $8,385,395.00$ & $10,472,135.00$ & $9,903,487.00$ & $7,541,626.00$ & $11,612,227.00$ \\
Temporary crops & $25,999,728.00$ & $31,615,963.00$ & $38,632,128.00$ & $42,244,221.00$ & $34,252,829.00$ & $48,234,391.00$ \\
Natural pasture & $124,406,233.00$ & $125,950,884.00$ & $113,897,357.00$ & $105,094,029.00$ & $78,048,463.00$ & $57,316,457.00$ \\
Planted pasture & $29,732,296.00$ & $39,701,366.00$ & $60,502,284.00$ & $74,094,402.00$ & $99,652,009.00$ & $101,437,409.00$ \\
Numbers of Animals & & & & & & \\
Cattle & $78,562,250.00$ & $102,673,753.00$ & $118,085,872.00$ & $128,041,757.00$ & $153,058,275.00$ & $171,613,337.00$ \\
Bubaline & $108,592.00$ & $209,077.00$ & $380,986.00$ & $619,712.00$ & $834,922.00$ & $885,119.00$ \\
Goats & $5,708,993.00$ & $6,709,428.00$ & $7,908,147.00$ & $8,207,942.00$ & $6,590,646.00$ & $7,107,608.00$ \\
Sheep & $17,643,044.00$ & $17,486,559.00$ & $17,950,899.00$ & $16,148,361.00$ & $13,954,555.00$ & $14,167,504.00$ \\
\hline
\end{tabular}

Source: [1].

the increase in Brazilian herd, shows an efficiency of the productive sector, producing more animals in a smaller amount of area. This has been possible due to advances in research on pasture and adaptations of plant characteristics to best fitness regions.

\section{Advances in Research on Grassland Ecosystems in Brazil}

The research of grassland ecosystems can be divided into three stages: extractive livestock, search for balance between individual performance and animal production per unit area and knowledge of the grass landecophysiology and grazing ecology.

Still very impressive today, extractive livestock uses up natural resources with a minimum of human interference. The use of the animal, fire and fences, allowed the control of vegetation for livestock enterprises are settled with some stability [2]. According to the author, this process still continues on a smaller scale as a first resort to penetrate, for example, in the Amazon. Research activities at this time were related to the method of sowing, use of herbicides and herd mineralization.

Then, research centers and universities began a search for new species for study and use in animal production. This period, according to [2] was known as the grass cycle, which sought to change quantitatively and qualitatively the pasture availability for a herd in free evolution. From that point, the plant material is assessed as their agronomic and forage qualities, expanding opportunities for new species, beyond the few grass used at the time, were studied in relation to responses to liming and fertilization, cutting systems, acceptance by animals, tolerance to pests, disease, cold, drought, grazing behavior and responses in different soils and climates.

Since their introductions, practically all grass, were and continue to be subjected to cutting systems, combining 
frequency, severity and levels of fertilization. Fertilizers, from simple formulations, making liming or not, have, in accordance with known regional needs to be supplemented with micronutrients. Nitrogen, the main growth promoter and dry matter production is still applied in different combinations with different times in an attempt to distribute the available forage throughout the year, in search of reduced seasonal production levels. Thus, numerous articles and newsletters with reference curves for responses of grass to fertilizer application at different levels and cutting systems have been published [6]-[13].

In Brazil, before the introduction of cultivated pastures in the Cerrado region, the stocking rate was 0.3 to 0.4 animals/ha and cattle only reached the age of slaughter after 48 to 50 months [14]. In the early 1970s began the introduction of the species of Brachiaria decumbens. According to [15], this species has adapted very well to the Cerrado biome, characterized by acidic soils and low fertility. According to the authors, the initial stocking rate was increased to 0.9 - 1.0 animal/ha and live weight gain also increased on average $2-3$ times. This increased productivity, they conclude, resulted in a big boost in farm beef cattle in Brazil and greatly expanded the agricultural frontier.

Currently, even with the forage breeding programs consolidation, which we saw in Brazil is that grassland ecosystems in general, are formed with a single grass, especially of the genera Brachiaria and Panicum. In the Cerrado, the Brachiaria still occupy the largest planted area with about $85 \%$ of total forage and the genus Panicum around 12\% [16]. According to [17], if the forage seed market in Brazil is analyzed the conclusion is unmistakably of a lack of diversity since $45 \%$ of the area and $60 \%$ of the seed production is of Brachiaria brizantha cv. Marandu and $90 \%$ of the seed exported is of four Brachiaria cultivars (www.estatexport.com.br). Thereby, there are several forage plants available and except in rare situations, there are forage options for all the different ecosystems in Brazil as well as for any type of intensification in animal production [18].

There is no doubt about the difference that this grass provided to the production system since its launch in 1983. The popularization and acceptance of marandu palisade grass between cattle breeders resulted in the establishment of this grass in large areas of monoculture [19] system. This demonstrates the importance and dimension of this plant to Brazilian cattle, particularly in the Cerrado region. However, the last decade has seen problems with the death of this grassland species in Brazil, especially in the Central and Northern regions. Such adoption becomes the production system vulnerable to abiotic and/or biotic stresses, able to reduce the productivityand quality of forage [20]. These events, known as the death of marandupalisadegrass syndrome, have enhanced the process of pasture degradation. As possible causes of mortality, [19] cite drought stress, problems with fertility and/or soil compaction, and infestation by fungi, bacteria and nematodes. Due to factors like these, is increasingly evident the importance of forage diversification in properties with livestock production base on pature system. Problems affecting the persistence of certain grass does not compromise or impede your system with diversification. In Brazil's case, not only the individual producers, but all the livestock sector due to the high rate of pasture with only this species.

For a long time, research on forage crops in Brazil emphasized studies on the curve of the herbage accumulation after cutting or grazing and their seasonal production and morphological composition, being herbage accumulation regarded as a unique, natural process, without taking into account dynamic aspects related to plant population and competition for light [21]. The authors mention that the only concern of researchers was, and in many cases still is, to achieve better economic results of the use of the pasture without worrying about basic aspects of the grassland ecophysiology and the grassland ecosystem harmony, in other words, the focus was on how to do and not on why do.

According to [17], at the end of the 1990's, the concepts related to the ecophysiology of tropical grass and grazing ecology received greater attention from researchers and were incorporated in the experimental protocols for pasture evaluation. The significant changes and advances that occurred regarding the understanding of important factors and processes that determine adequate use of tropical grass in pastures can be found in the review paper by [17] [21]. From these observations, studies were initiated not only on the grassland ecophysiologiy, but also on the dynamics of the grazing process and their interactions. These studies have allowed understanding the inter-relationships with forage intake, to understand the animal production systems on pasture and also about the plant-animal complex in pastoral systems. Currently, studies have been based on the dynamics of herbage accumulation, morphogenesis, resistance to grazing, phenotypic plasticity, population dynamics, grazing dynamics, feeding behavior and forage intake, forage composition and their nutritional value, biochemical aspects of feeding behavior. Right now, it is clear that more important than producing forage in large quantities is harvest this forage produced efficiently. 
Thus, knowledge on the morphogenesis, grassland ecophysiology and grazing ecology has acquired great importance, assuming a prominent role and constitute basic premise for the idealization and recommended practices of sustainable management, which increase the production and productivity of production systems, respecting the limits and the specific characteristics of the grassland ecosystem [22]. This change in paradigm has generated a large database which has guided strategies for pasture utilization.

The paradigm shift in studies of tropical forage plants in Brazil based on the model described by [23]-[25]. This model portrays the soil-plant-animal relationship and has shown important information regarding the responses of forage plants and animals in different grazing strategies.

Based on the above model, many studies related to the morphogenesis of forage plants has been carried out in Brazil. Quick search in SciELO, Scientific Electronic Library Online, with terms morphogenesis, morphogenic, morphogenetic and grass, showed more than 50 papers published in national journals indexed to its base since 2005. This shows great gains in information for application to different grazing strategies for both continuous and intermittent stocking.

Research results have shown that the concept of critical Leaf Area Index, LAI, condition in which the canopy intercepts $95 \%$ of the incident light, originally described and successfully applied for temperate plants, is valid and can also be applied to tropical grasses [26]-[32]. Besides the interception of light, similar relationships were also found to herbage accumulationand morphological composition and nutritive value of forage produced [33]-[35].

According to [36], the set and response patterns under different strategies of tropical grazing forage plants is a result of changes in the structure of the sward along the regrowth, characterized by significant changes in the proportion and distribution of leaves, stem and dead material in the vertical profile of the canopy, leaf:stem ratio, the bulk density of herbage and the leaf final length, among others. [21] reported that even with the significant morphological variation of species assessed, different experimental sites and grazing methods employed, results demonstrate the importance of the sward structure and its characteristics have on the accumulation and nutritive value of forage produced and, consequently, on feeding behavior, intake and grazing animals performance (Figure 3).

\section{Future Prospects}

Conceptually, Crop and Livestock Integration System, CLIS, is a strategy for sustainable production, which integrates agricultural, livestock and forestry activities in the same area, in intercropping, in succession or rotated, and seeks synergistic effects between the components of agroecosystems, contemplating the environmental suitability, appreciation of the man and the economic viability [37].

In different biomes, the CLIS potential adoption is subject to a number of economic and environmental factors, and characteristics of these regions. According to [37], in the case of the Cerrado, until the mid-1960s, agricultural activities in this region were limited and directed to the extensive production of beef cattle, because soils were infertile for agricultural production. This usage model, extractive, as seen above, led to accelerated degradation of most of these areas. Pasture degradation is by far the most important problem of livestock production in Brazil. Over 100 million ha of cultivated pasture is under exploitation in the country nowadays, but about $60 \%$ are estimated to be in varying degrees of degradation [38].

In the CLIS occurs the complementarity and synergy between the biotic and abiotic components, so that the available means of production can be used efficiently [37]. According to the authors, the propositions of CLIS strategy advocate for the diversification of agricultural and pastoral activities and improve the use of environmental resources, with advantages from different perspectives regarding the technological, ecological, social and economic components of the different actors. With CLIS, costs of fertilizer, soil preparation, seeds, etc., used to recuperate pastures and improve soil fertility can be compensated when this system is utilized.

There are still many questions about the proper pasture management in CLIS. The vast majority of grazing management and pasture related works are results of experiments on single pasture. The way the components relate and their answers are the subject of recently research undertaken by research centers and universities in Brazil, whose results are still preliminary. Furthermore, there is great expectation in CLIS, since the large capacity of carbon storage in soils under grassland led the Brazilian Government to establish as a major goal reduce emissions of greenhouse gases-Voluntary Commitment Brazil made during the UN Conference on Climate Change (COP-15) held in 2009 in Copenhagen, Switzerland — the recovery of 15 million hectares by 2020 [39]. 
According to [17], this scientific-technological knowledge is strategic for Brazil since it will contribute for a better understanding about adequate management of animal production systems in order to minimize impacts and derive environmental, economic and social benefits. In addition, it would enlighten the Brazilian society about the true benefits and drawbacks of animal production and strengthen the country's position for international negotiations as well as provide arguments to neutralize potential embargoes.

\section{References}

[1] Institutobrasileiro de Geografia E Estatística (2006) Agricultural Census.

[2] Rocha, G.L. (1988) The Evolution of Research on Forage Crops and Pastures in Brazil. ESALQ, Piracicaba 45 (part1), 5-51.

[3] Girardi, E.P. (2008) Atlas of Brazilian Agrarian Question. Presidente Prudente. http://www2.fct.unesp.br/nera/atlas/estrutura_fundiaria.htm

[4] Sano, E.E., Rosa, R., Brito, J.L.S. and Ferreira, L.G. (2008) Semidetailed Land Use Mapping in the Cerrado. Pesquisa Agropecuária Brasileira, 43. http://dx.doi.org/10.1590/S0100-204X2008000100020

[5] Rallyfarming. 2012. http://www.rallydapecuaria.com.br

[6] Werner, J.C., Paulino, V.T., Cantarella, H., et al. (1996) Forrageiras. In: Raij, B., Cantarella, H., Quaggio, J.A., et al. (Eds.), Recomendações de Adubação e Calagem para o Estado de São Paulo, Instituto Agronômico, Campinas, 285p. (Boletim, 100).

[7] Martha Jr., Vilela, G.B.L. and Sousa, D.M.G. (2007) Nitrogenfertilization. In: Martha Jr., G.B., Vilela, L. and Sousa, D.M.G., Eds., Cerrado: Uso Eficiente de Corretivos e Fertilizantes em Pastagens, Embrapa Cerrados, Planaltina.

[8] Colozza, M.T., Kiehl, J.C., Werner, J.A. and Schammass, E.A. (2000) Responses of Panicum maximum cv. Aruana to rates of nitrogen. Boletimde Indústria Animal, Nova Odessa, 57, 21-32.

[9] Sousa, D.M.G., Vilela, L., Lobato, E. and Soares. W.V. (2001) Use of Gypsum, Lime and Fertilizer to Pastures in the Cerrado. Embrapa Cerrados, Planaltina. (Embrapa Cerrados. Circular Técnica, 12).

[10] Macedo, M.C.M., Machado, J.L. and Valle, C.B. (2004) Response of Promising Cultivars and Access of BrachiariaBrizanthato Phosphorus at Two Levels of Base Saturation. In: Reunião Anual Da Sociedade Brasileira Dezootecnia, 41, SBZ, Campo Grande.

[11] Monteiro, F.A. (2004) Concentration and Distribution of Nutrients in Forage Grasses and Legumes. In: Simpósio Sobre Manejo Estratégico Dapastagem, 2, UFV, Viçosa.

[12] Corsi, M. (1994) Nitrogen Fertilizer on Pastures. In: Peixoto, A.M., Moura, J.C. and Faria, V.P., Eds., Pastagens: Fundamentos da Exploração Racional, Fundação de Estudos Agrários Luiz de Queiroz, Piracicaba.

[13] Cantarutti, R.B., Martins, C.E., Carvalho, M.M., et al. (1999) Pastagens. In: Ribeiro, A.C., Guimarães, P.T.G. and Alvarez, V.H., Eds., Comissão de Fertilidade do Solo do Estado de Minas Gerais: Recomendação Para Uso de Corretivos e Fertilizantes em Minas Gerais—5 $5^{\text {a }}$ Aproximação, UFV, Viçosa.

[14] Arruda, Z.J. (1994) The Beef Cattle in Brazil and Prospects for the Sector. Embrapa-CNPGC, Campo Grande, 28p. (Documentos, 60)

[15] Macedo, M.C.M. and Araújo, A.R. (2012) Integrated Crop-Livestock: Alternatives for Degraded Pastures Recuperation. Integrated Crop-Livestock-Forest; Sustainable Production. 2nd Edition, Embrapa, Brasília, DF.

[16] Macedo, M.C.M. (2005) Pastures in Cerrado Ecosystem: The Evolution of Research for Sustainable Development. In: Reunião Anual da Sociedade Brasilaira de Zootecnia, 42, SBZ, Goiânia, 56-84.

[17] Euclides, V.P.B., Valle, C.B., Macedo, M.C.M., Almeida, R.G., Montagner and D.B., Barbosa, R.A.( 2010) Brazilian Scientific Progress in Pasture Research during the First Decade of XXI Century. Brazilian Journal of Animal Science, 39, 151-168.

[18] Lupinacci, A.V. (2003) Release of Cultivars of Forage Plants: A Critical Review. In: Simpósio Sobre Manejo da Pastagem, 20, Fealq, Piracicaba.

[19] Marchi, C.E., Fernandes, C.D., Santos, J.M., Jerba, V.F. and Fabris, L.R. (2006) Mortality of Brachiaria brizantha Marandu: Pathological Cause? In: Barbosa, R.A., Ed., Morte de Pastos de Braquiárias, Embrapa Gado de Corte, Campo Grande.

[20] Verzignassi, J.R. and Fernandes, C.D. (2001) Grasslandsdisease. Embrapa Gado de Corte, Campo Grande. (Embrapa Gado de Corte. Divulga, 50).

[21] Da Silva, S.C. and Nascimento Jr., D. (2007) Advances in Research on Tropical Foragesin Pastures: Physiological and Morphological Traits and Grazing Management. Brazilian Journal of Animal Science, 36, 121-138. 
[22] Nascimento Jr., D., Barbosa, R.A., Marcelino, K.R.A., et al. (2003) Livestock Production in Pastures in Brazil: Use of Technical Knowledge and Results. In: Peixoto, A.M., Moura, J.C., Da Silva, S.C. and De Faria, V.P., Eds., Simpósio Sobre Manejo da Pastagem, 20, FEALQ, Piracicaba.

[23] Chapman, D.F. and Lemaire, G. (1993) Morphogenetic and Structural Determinats of Plant Regrowth after Defoliation. In: Baker, M.J., Ed., Grassands for Our World, Sir Publishing, Wellington, 55-64.

[24] Sbrissia, A.F. and Da Silva, S.C. (2001) Pasture Ecosystem and Livestock Production. In: Pedreira, C.G.S. and Da Silva, S.C., Eds., A Produção Animal na Visão dos Brasileiros, Fundação de Estudos Agrários Luiz de Queiroz, Piracicaba.

[25] Da Silva, S.C. and Nascimento Jr., D. (2006) Grassland Ecophysiology. In: Pereira, O.G., Obeid, J.A., Nascimento Jr., D. and Fonseca, D.M., Eds., Simpósio Sobre Manejo Estratégico da Pastagem, III, UFV, Viçosa.

[26] Montagner, D.B., Nascimento Jr., D., Vilela, H.H., Sousa, B.M.L., Euclides, V.P.B., Silva, S.C. and Carloto, M.N. (2012) Tillering Dynamics in Pastures of Guinea Grass Subjected to Grazing Severities under Intermittent Stocking. Revista Brasileira de Zootecnia, 41, 544-549.

[27] Souza Jr., S.J. (2007) Sward Structure, Light Interception and Herbage Accumulation of Marandupalisadegrass Subjected to Rotational Grazing Strategies by Beef Cattle. Dissertation (Masterin Agronomy), Luiz de Queiroz College of Agriculture/University of São Paulo, Piracicaba.

[28] Carnevalli, R.A., Da Silva, S.C., Bueno, A.A.O., et al. (2006) Herbage Production and Grazing Losses in Panicum maximum cv. Mombaça under Four Grazing Managements. Tropical Grasslands, 40, 165-176.

[29] Moreno, L.S.B. (2004) Forage Yield of Panicum Grasses and Modeling Yield, Morphological and Physiological Traits in Response to Climatic Variables. Dissertation (MasterinAgronomy), Luiz de Queiroz College of Agriculture/ University of São Paulo, Piracicaba.

[30] Voltolini, T.V., Santos, F.A.P., Martinez, J.C., Imaizumi, H., Clarindo, R.L. and Penati, M.A. (2010) Milk Production and Composition of Dairy Cows Grazing Elephant Grass under Two Grazing Intervals. Brazilian Journal of Animal Science, 39.

[31] Zeferino, C.V. (2006) Morphogenesis and Dynamics of Herbage Accumulation in Marandupalisadegrass Swards [Brachiariabrizantha (Hochst. ex A. Rich) cv. Marandu] Subjected to Regimes of Intermittent Stocking by Beef Cattle. Dissertation (Masterin Agronomy), Luiz de Queiroz College of Agriculture/University of São Paulo, Piracicaba.

[32] Barbosa, R.A., Nascimento Jr., D., Euclides, V.P.B., et al. (2007) Tanzânia Grass Subjected to Combinations of Intensity and Frequency of Grazing. Pesquisa Agropecuária Brasileira, 42, 329-340.

[33] Bueno, A.A.O. (2003) Canopy Structural Characteristics, Nutritive Value and Herbage Production of Mombaça Grass Pastures Submmited to Intermitent Defoliation Regimes. Dissertation (MasterinAgronomy), Luiz de Queiroz College of Agriculture/University of São Paulo, Piracicaba.

[34] Difante, G.S., Euclides, V.P.B., Nascimento Jr., D., Silva, S.C., Torres Jr., R.A.A. and Sarmento, D.O.L. (2009) Ingestive Behaviour, Herbage Intake and Grazing Efficiency of beef Cattle Steers on Tanzania Guineagrass Subjected to Rotational Stocking Managements. Brazilian Journal of Animal Science, 38, 1001-1008.

[35] Sarmento, D.O.L. (2007) Herbage Accumulation, Morphological Composition and Nutritive Value in Brachiariabrizantha (Hochst ex A. Rich) Stapf.cvMarandu Subjected to Rotational Stocking Strategies with Beef Cattle. Ph.D. Thesis (MasterinAgronomy), Luiz de Queiroz College of Agriculture/University of São Paulo, Piracicaba.

[36] Da Silva, S.C. and Carvalho, P.C.F. (2005) Foraging Behaviour and Herbage Intake in the Favourable Tropics/Subtropics. In: McGilloway, D.A., Ed., Grassland: A Global Resource. Wageningen Academic Publishers, Wageningen.

http://books.google.com.br/books?hl=pt-BR\&lr=\&id=ry nFm-je6kC\&oi=fnd\&pg=PA81\&dq=Foraging+Behaviour+a nd+Herbage+Intake+in\&ots=I9Jyrb5IrG\&sig=TQnWSjYynzmajd9vpsEFBrGXz74\#v=onepage\&q=Foraging\%20Beha viour\%20and\%20Herbage\%20Intake\%20in\&f=false

[37] Balbino, L.C., Barcellos, A.O. and Stone, L.F. (2011). Referencedocumentcrop-Livestock-Forestryintegration. Embrapa, Brasília, 130p.

[38] Macedo, M.C.M. (2009) Integração Lavoura e Pecuária: O Estado da Arte e Inovações Tecnológicas. Revista Brasileira de Zootecnia, 38, 133-146. http://dx.doi.org/10.1590/S1516-35982009001300015

[39] Ministério Da Agricultura, Pecuária E Abastecimento-Sustainabledevelopment-ABCProgram. 2014.

http://www.agricultura.gov.br/desenvolvimento-sustentavel/programa-abc. 